\title{
FORMULASI TEPUNG TEMPE DAN SARI WORIEL PADA PEMBUATAN MIE BASAH KAYA GIZ
}

\author{
Asmawati ${ }^{1 *}$, Adi Saputrayadi ${ }^{2}$, Mulqan Bulqiah ${ }^{3}$ \\ ${ }^{1}$ Teknologi Hasil Pertanian, Universitas Muhammadiyah Mataram, asmawatiraba@gmail.com* \\ ${ }^{2,3}$ Teknologi Hasil Pertanian, Universitas Muhammadiyah Mataram
}

\section{INFO ARTIKEL}

RiwayatArtikel:

Diterima: 05-10-2018

Disetujui : 09-01-2019

\section{Kata Kunci:}

Mie basah

Sari wortel

Tepung tempe

Kaya gizi

\begin{abstract}
ABSTRAK
Abstrak: Penelitian ini bertujuan untuk mengetahui pengaruh formulasi tepung tempe dan sari wortel pada pembuatan Mie basah kaya gizi. Metode yang digunakan adalah Metode Eksperimental yang ditata dengan menggunakan Rancangan Acak Lengkap ( RAL) perlakuannya sebagai berikut : formulasi tepung tempe dan sari wortel dalam pembuatan mie basah kaya gizi yaitu $100 \%, 10 \%+30 \%, 15 \%+25 \%, 20 \%+20 \%, 25 \%+15 \%, 30 \%+10 \%$. Data hasil pengamatan dianalisis dengan menggunakan analisis keragaman pada taraf nyata $5 \%$, di uji lanjut dengan Uji Beda Nyata Jujur pada taraf nyata 5\%. Hasil penelitian menunjukkan bahwa formulasi tepung tempe dan sari wortel pada pembuatan mie basah kaya gizi berpengaruh secara nyata terhadap kadar protein dan semua sifat organoleptik (tekstur, warna, aroma dan rasa), tetapi tidak berpengaruh secara nyata terhadap kadar air dan kadar betakaroten mie basah. Semakin tinggi formulasi tepung tempe yang diberikan maka kadar protein semakin meningkat, tetapi kadar air dan kadar betakaroten semakin menurun, skor nilai tekstur, aroma, warna, dan rasa semakin meningkat dan disukai oleh panelis. Perlakuan terbaik diperoleh pada perlakuan T5 (Formulasi tepung tempe $30 \%+10 \%$ ) yaitu dengan nilai kadar air 4,33\%, kadar protein $11,22 \%$, dan mempunyai tekstur yang kenyal, berwarna kuning agak oranye, aroma sangat disukai dan rasa disukai panelis.
\end{abstract}

\section{A. LATAR BELAKANG}

Mie merupakan bahan pangan yang cukup potensial, selain harganya relatif murah dan pengolahannya yang praktis. Mi memiliki kandungan gizi yang cukup baik terutama kandungan karbohidrat yang tinggi, sehingga mi disukai masyarakat sebagai sumber karbohidrat pengganti nasi yang mengenyangkan dan merupakan makanan favorit mulai anak-anak hingga lanjut usia. Saat ini berbagai jenis mi telah banyak di konsumsi dan dijual di pasaran. Mi basah adalah salah satu bentuk mi yang mudah diolah oleh masyarakat umum dan bahanbahan pembuatan mi pun mudah didapat, dimana kemungkinan setiap orang dapat membuatnya sendiri [1]. Mi basah yang ideal adalah mi yang memenuhi syarat SNI 01-2987-1992, yaitu memiliki warna, bau, dan rasa yang normal, kadar air 20-35\%, kadar abu dan protein minimal 3\%.

Bahan utama dalam pembuatan mi adalah tepung terigu yang biasa dikonsumsi hanya mengandung zat gizi makro saja yaitu karbohidrat, protein dan lemak, dan sangat sedikit atau bahkan tidak mengandung zat gizi mikro seperti vitamin dan mineral, sehingga diharapkan dengan penambahan tepung tempe dan sari wortel dapat memperbaiki kandungan gizi mi basah yang kaya akan gizi.

Tempe merupakan bahan makanan hasil fermentasi kedelai yang menggunakan jamur Rhizopus oligosporus atau Rhizopus oryzae. Tempe dapat diperoleh dengan harga yang lebih terjangkau dan lebih mudah diperoleh. Tempe merupakan sumber gizi yang baik kerena mengandung protein, asam amino esensial, asam lemak esensial, vitamin B kompleks, dan serat dalam jumlah cukup [2].

Tempe kedelai memiliki serat kasar yang merupakan karbohidrat atau polisakarida sebanyak 7,2 g/ $100 \mathrm{~g}$ bahan yang tidak dapat. dicerna oleh tubuh. Walaupun serat kasar tidak memberi nilai gizi yang tidak berarti bagi tubuh tetapi berperan sangat penting bagi kesehatan pencernaan [3].

Tepung tempe adalah tepung yang terbuat dari tempe yang dikukus lalu dijemur sampai kering dan digiling menjadi tepung. Pengolahan tempe menjadi tepung memiliki banyak manfaat, antara lain tepung tempe mudah disimpan, ataupun diolah menjadi makanan cepat saji dan dapat digunakan sebagai bahan baku pengganti tepung atau digunakan bersama tepung terigu. Manfaat tepung tempe yang lain adalah dapat meningkatkan kadar protein pada produk, dan membantu mengurangi ketergantungan masyarakat akan tepung terigu, sehingga tepung tempe dapat dijadikan sebagai pensubstitusi tepung terigu [4]. Adapun komposisi (\% bahan kimia ) dan nilai gizi pada tepung tempe yaitu : protein $48,0 \mathrm{mg}$; lemak $24,7 \mathrm{mg}$; karbohidrat 13,5 mg; serat 2,5 mg; abu 2,3 mg; dan nilai cerna $87 \mathrm{mg}$ [1]. 
Wortel merupakan sayuran yang kaya akan betakaroten sebagai antioksidan yang bisa mencegah penyakit jantung, kanker kulit dan penuaan dini. Wortel dikenal memiliki kandungan vitamin A yang sangat tinggi. Wortel memiliki zat gizi lain seperti kalori, protein, kalsium, dan besi [5].

[6] melaporkan bahwa terigu jenis "soft" cap kunci dapat disubstitusi dengan tepung sorgum sampai $10 \%$ dalam pembuatan mie kering dengan hasil yang disukai panelis. [7] melaporkan bahwa terigu jenis medium cap segitiga biru dapat disubstitusi dengan tepung sagu sampai $30 \%$ dalam pembuatan mie basah. Sedangkan penelitian [8] melaporkan bahwa jumlah maksimum tepung ubi kayu $20 \%$ yang dapat menstubtitusi terigu dalam pembuatan mie. [9] telah melakukan penelitian substitusi bubur wortel terhadap terigu dan melaporkan bahwa bubur wortel dapat digunakan sebagai bahan substitusi tepung terigu pada pembuatan mi basah sebesar $20 \%$.

Dari peneliti dilakukan [9] masih terdapat keunggulan dan kelemahan sehingga tercetuslah ide untuk membuat mi basah dengan penambahan tempe dan wortel dengan perbandingan 25\%, yang dapat disubstitusikan pada pembuatan mi basah.

Berdasarkan penelitian pendahuluan bahwa persentasi tempe dan wortel sebanyak $25 \%$ dengan disubstitusikan dengan terigu pada pembuatan mie basah menghasilkan adonan mi yang dapat dibentuk.

Berdasarkan uraian di atas, maka perlu diadakan suatu penelitian untuk mengetahui formulasi terbaik tepung tempe dan sari wortel pada pembuatan mi basah kaya gizi.

\section{B. METODE PENELITIAN}

\section{Metode Penelitian}

Metode yang digunakan dalam penelitian ini adalah metode eksperimental dengan melakukan percobaan di laboratorium.

\section{Rancangan Penelitian}

Rancangan yang digunakan dalam penelitian ini adalah Rancangan Acak Lengkap (RAL) dengan 2 faktor yaitu Formulasi tepung tempe dan sari wortel dalam pembuatan mi basah kaya gizi dengan perlakuan sebagai berikut:

TO : Formulasi tepung Terigu $100 \%$ ( kontrol)

T1 : Formulasi tepung tempe $10 \%+30 \%$ Sari Wortel $+60 \%$ Tepung Terigu

T2 : Formulasi tepung tempe 15\% + 25\% Sari Wortel + $60 \%$ Tepung Terigu

T3 : Formulasi tepung tempe 20\%+20\% Sari Wortel $+60 \%$ Tepung Terigu

T4 : Formulasi tepung tempe $25 \%+15 \%$ Sari Wortel $+60 \%$ Tepung Terigu

T5 : Formulasi tepung tempe 30\% + $10 \%$ Sari Wortel $+60 \%$ Tepung Terigu
Setiap perlakuan membutuhkan berat sampel 250 gr (Campuran tepung tempe + Sari wortel + tepung terigu). Data hasil pengamatan analisis dengan menggunakan analisis keragaman (anova) pada taraf nyata 5\%, maka di uji lanjut dengan Uji Beda Nyata jujur (BNJ ) pada taraf nyata 5\% [10].

\section{Waktu dan Tempat Penelitian}

Penelitian dilaksanakan pada bulan Mei - Juni 2018 di Laboratorium Teknologi Hasil Pertanian Fakultas Pertanian Universitas Muhammadiyah Mataram.

\section{Bahan dan Alat}

a. Bahan Penelitian

Bahan- bahan yang digunakan dalam penelitian ini yaitu : Wortel jenis nantes, tepung tempe, tepung terigu minyak merek bimoli , garam ,telur, dan air, Soda abu (Natrium Karbonat dan Kalium Karbonat) Bahan- bahan kimia antara lain: $\mathrm{Zn}, \mathrm{NaOH}$, asam borat, larutan bromcresol green, larutan metil, alkohol 95\%, $\mathrm{HCl}, \mathrm{KOH}, \mathrm{Na}_{2} \mathrm{SO}_{4}$.

b. Alat Penelitian

Peralatan yang digunakan dalam penelitian ini adalah pisau, blender, baskom besar, mixing, rool press, wajan, kompor, saringan/ ayakan, panci pengukus, serok, alat kayu berbentuk sunder timbangan digital, oven, lemari pendingin, labu, cawan, dan desikator.

\section{Pelaksanaan Penelitian}

Tahapan-tahapan dalam proses pelaksanaan Penelitian sebagai berikut:

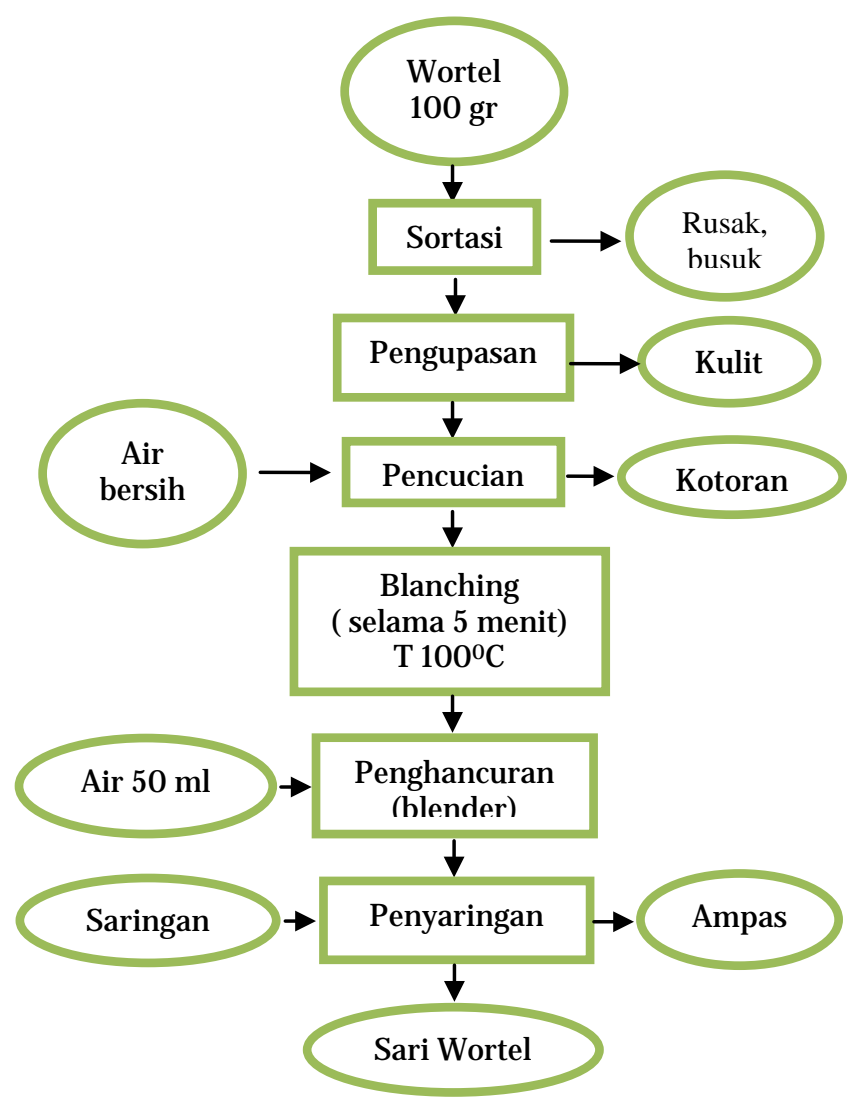


Gambar 1. Diagram alir proses pembuatan sari wortel modifikasi [11]

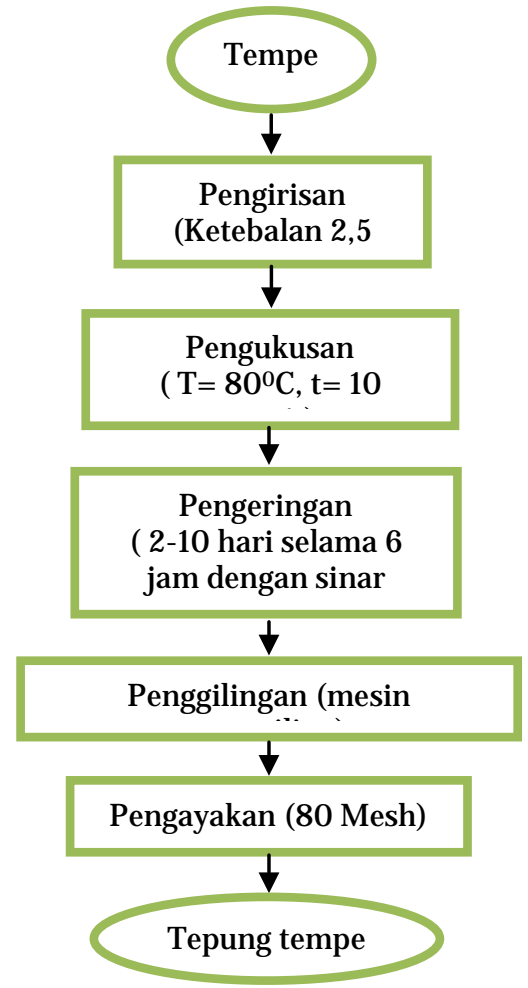

Gambar 2. Diagram alir pembuatan tepung tempe modifikasi

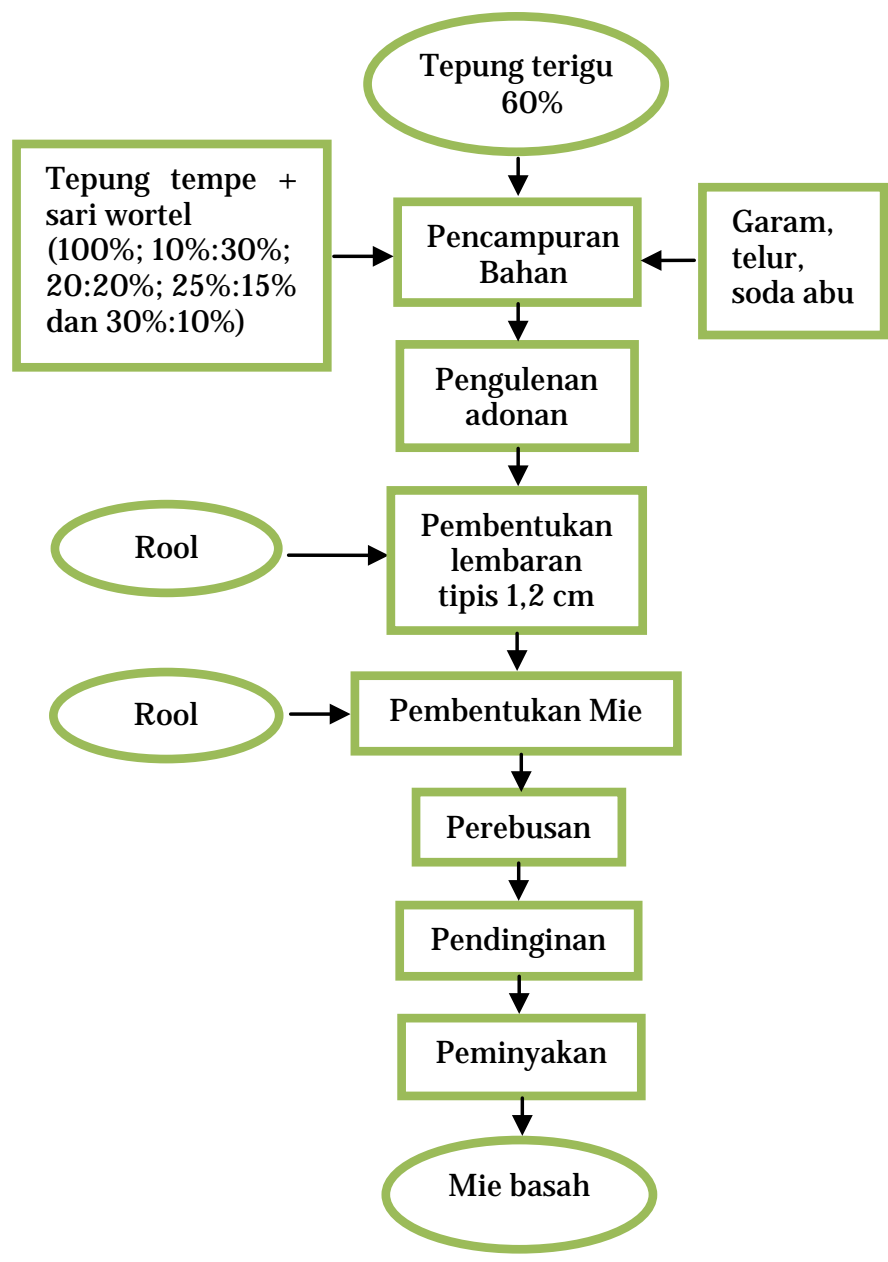

Gambar 3. Diagram alir pembuatan mie basah modifikasi tepung tempe dan sari wortel modifikasi [12]

\section{HASIL DAN PEMBAHASAN}

\section{Kadar air}

Grafik hubungan pengaruh formulasi tepung tempe dan sari wortel pada pembuatan mi basah kaya gizi dapat dilihat pada Gambar 4.

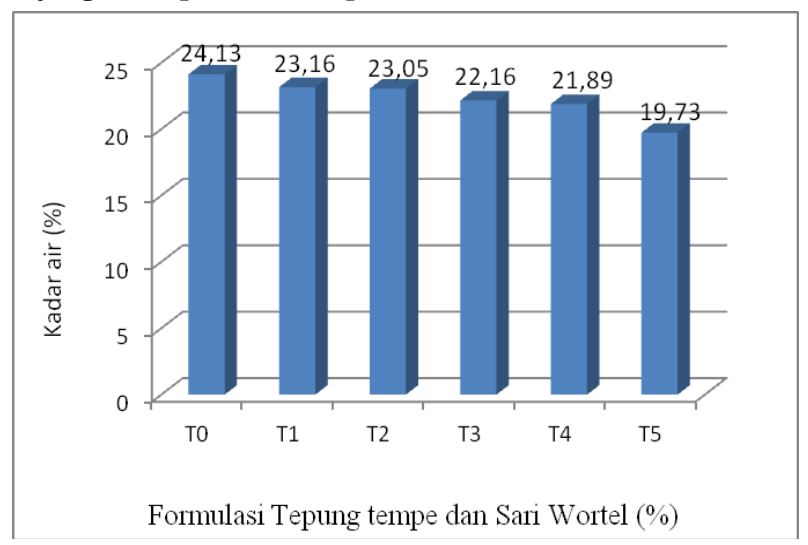

Gambar 4. Grafik hubungan pengaruh formulasi tepung tempe dan sari wortel terhadap kadar air Mie basah kaya gizi

Gambar 4 menunjukkan bahwa semakin tinggi persentase fomulasi tepung tempe dan semakin rendah sari wortel, maka kadar air mie basah cenderung semakin rendah. Kadar tertinggi secara matematis cenderung tinggi diperoleh pada perlakuan T0 (25,13\%) dan terendah pada perlakuan T5 (19,73\%).

Kecenderungan rendahnya kadar air yang diperoleh pada perlakuan T5 (penambahan tepung tempe dan sari wortel 30\%+10\%) sebesar 19,73\% disebabkan karena persentase tepung tempe yang ditambahkan tinggi (30\%) dan sari wortel rendah (10\%). Tingginya kadar air pada produk mie basah dipengaruhi pula oleh proses pengolahan yaitu pada tahap perebusan. Hal ini sesuai dengan penjelasan [13] mengungkapkan bahwa mie mempunyai kadar air tinggi karena proses perebusan yang menyebabkan terjadinya gelatinisasi pati.

\section{Kadar Protein}

Grafik pengaruh hubungan formulasi tepung tempe dan sari wortel pada pembuatan mie basah kaya gizi dapat dilihat pada Gambar 5.

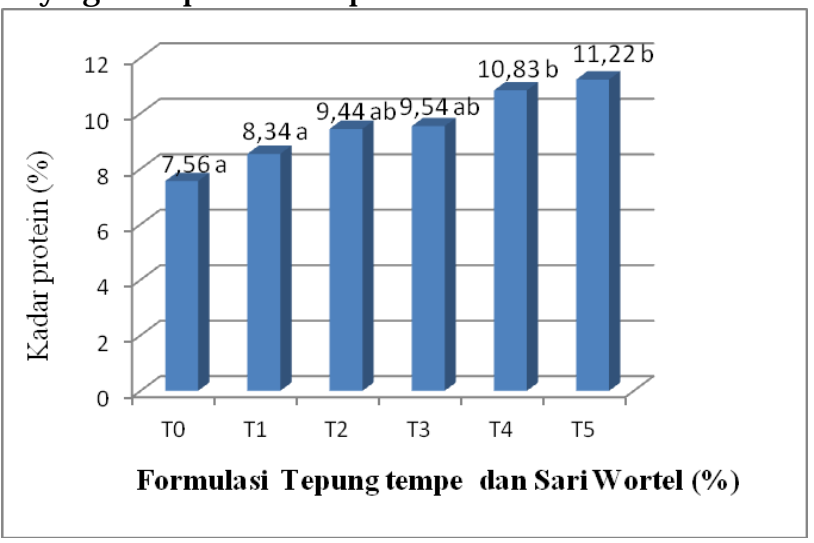


Gambar 5. Grafik pengaruh hubungan formulasi tepung tempe dan sari wortel terhadap kadar protein Mie basah kaya gizi.

Formulasi tepung tempe dan sari wortel memberikan pengaruh nyata terhadap kadar protein mie basah yang dihasilkan. Semakin tinggi formulasi tepung tempe yang ditambahkan maka kadar protein semakin meningkat. Hasil tertinggi diperoleh pada perlakuan T5 (tepung tempe 30\%, dan sari wortel 10\%) dengan kadar protein 11,22\%, sedangkan hasil terendah adalah T0 (tanpa penambahan tepung tempe dan sari wortel) dengan kadar protein 7,56\%.

Tingginya kadar protein pada perlakuan T5 (11,22\%), disebabkan karena tepung tempe mengandung kadar protein tinggi. Menurut [14] bahwa protein nabati yang mendekati hewani adalah dari kedele atau tempe. Protein pada tepung tempe juga ikut meningkatkan kandungan protein mie basah yang dihasilkan, kandungan protein pada tepung tempe sebesar 46,5 gr dalam $100 \mathrm{gr}$.

Tempe mengandung zat gizi lain dan bermanfaat seperti asam lemak, vitamin yang larut dalam air (vitamin B kompleks), dan vitamin yang larut dalam lemak (vitamin A, D, E, K), mineral (besi, tembaga, zink, kalsium, magnesium, dan fosfor) dan antioksidan yang sangat dibutuhkan oleh tubuh untuk menghentikan reaksi pembentukan radikal bebas [2].

\section{Kadar Betakaroten}

Grafik pengaruh hubungan formulasi tepung tempe dan sari wortel pada pembuatan mie basah kaya gizi dapat dilihat pada Gambar 6.

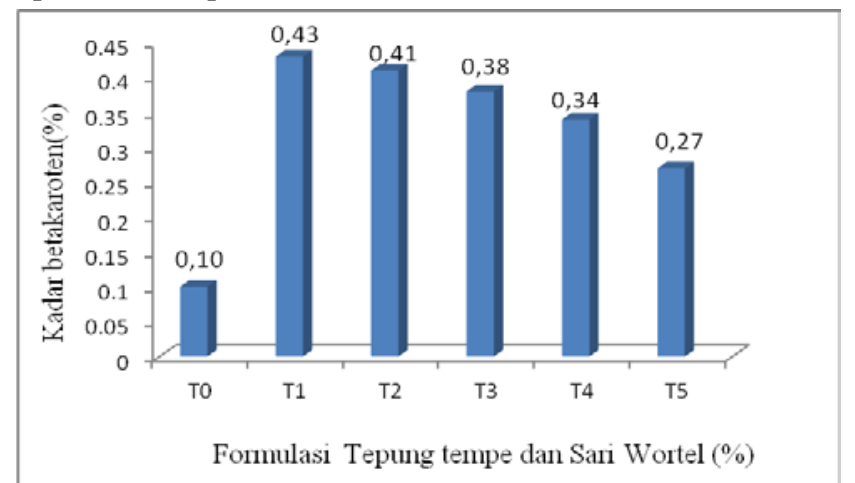

Gambar 6. Grafik pengaruh hubungan formulasi tepung tempe dan sari wortel terhadap kadar betakroten mie basah kaya gizi

Formulasi tepung tempe dan sari wortel tidak berbeda nyata terhadap kandungan betakaroten mie basah yang dihasilkan. Kadar betakaroten tertinggi diperoleh pada perlakuan T1 dengan formulasi sari wortel $30 \%$ sebesar $0,43 \%$, sedangakan perlakuan terendah T0 tanpa formulasi sari wortel sebesar $0,10 \%$. Wortel merupakan sayuran yang kaya akan betakroten dan dapat berfungsi sebagai antioksidan yang bisa mencegah penyakit jantung, kanker kulit dan penuaan dini. Wortel dikenal memiliki kandungan vitamin A yang sangat tinggi [5]

\section{Skor Nilai Tekstur}

Grafik pengaruh hubungan formulasi tepung tempe dan sari wortel terhadap skor nilai tekstur mi basah dapat dilihat pada Gambar 7.

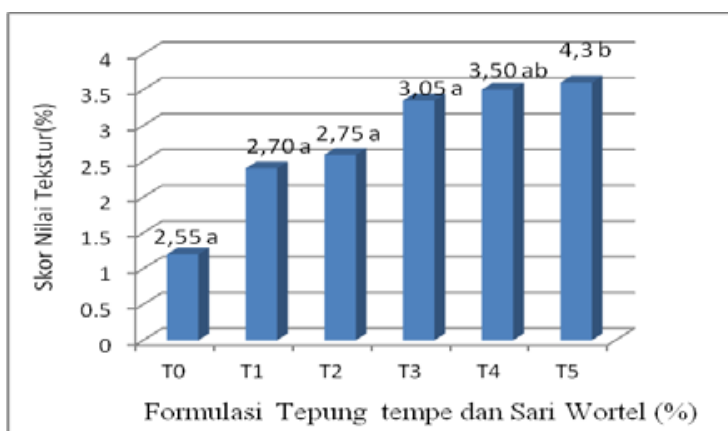

Gambar 7. Grafik pengaruh hubungan formulasi tepung tempe dan sari wortel terhadap skor nilai Tekstur Mie basah kaya gizi

Formulasi tepung tempe dan sari wortel pada mie basah memberikan pengaruh nyata terhadap skor nilai tekstur yang dihasilkan. Pada perlakuan T5 (formulasi tepung tempe 30\% dan sari wortel $10 \%$ ) diperoleh skor nilai tekstur sebesar 4,3 dengan kriteria kenyal dan skor nilai tekstur terendah diperoleh pada perlakuan T0 (kontrol : tepung terigu $100 \%$ ) yaitu sebesar 2,55 dengan kriteria mendekati agak kenyal. Hal ini disebabkan karena mie basah dengan penambahan tepung tempe memiliki kandungan gluten yang rendah, sedangkan tanpa penambahan tepung tempe banyak mengandung gluten. Besarnya protein pembentuk gluten menentukan sifat adonan dan produk yang dihasilkan. Gluten memberikan viskoelastisitas pada adonan dan menjadi produk akhir kenyal. Oleh karena itu gluten sangat dibutuhkan untuk memberikan elastisitas pada mie basah ( Abidin, 2009).

\section{Skor Nilai Warna}

Grafik pengaruh hubungan formulasi tepung tempe dan sari wortel terhadap skor nilai warna Mi basah dapat dilihat pada Gambar 8 sebagai berikut:

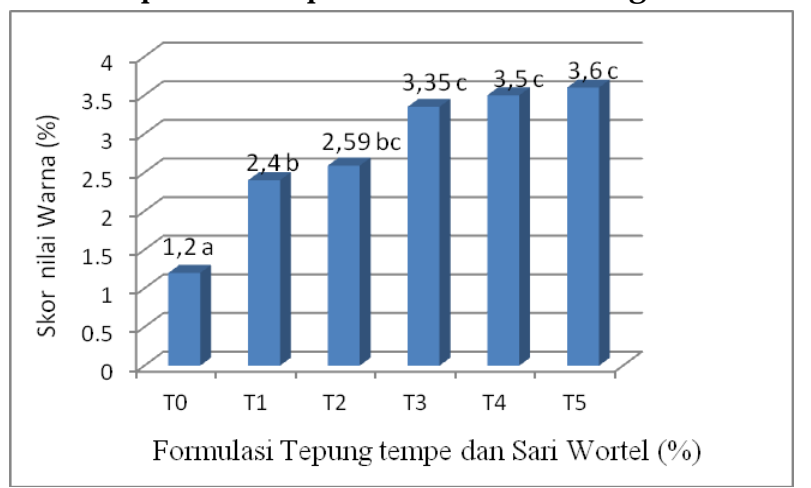

Gambar 8. Grafik pengaruh hubungan formulasi tepung tempe dan sari wortel terhadap skor nilai warna mie basah kaya gizi.

Formulasi tepung tempe dan sari wortel memberikan pengaruh nyata terhadap skor nilai 
warna mie basah yang dihasilkan. Skor nilai warna tertinggi diperoleh pada perlakuan T5 $(3,6)$ dengan kriteria kuning agak oranye dan skor nilai terendah diperoleh pada perlakuan T0 $(1,2)$ dengan kriteria putih.

Warna tepung tempe dan sari wortel yang diformulasikan menghasilkan warna mie basah yang cenderung disukai panelis. Kandungan karatenoid yang tinggi pada wortel dapat dimanfaatkan sebagai bahan pewarna alami [11].

\section{Skor Nilai Aroma}

Grafik pengaruh hubungan formulasi tepung tempe dan sari wortel terhadap skor nilai aroma mie basah dapat dilihat pada Gambar 9, sebagai berikut:

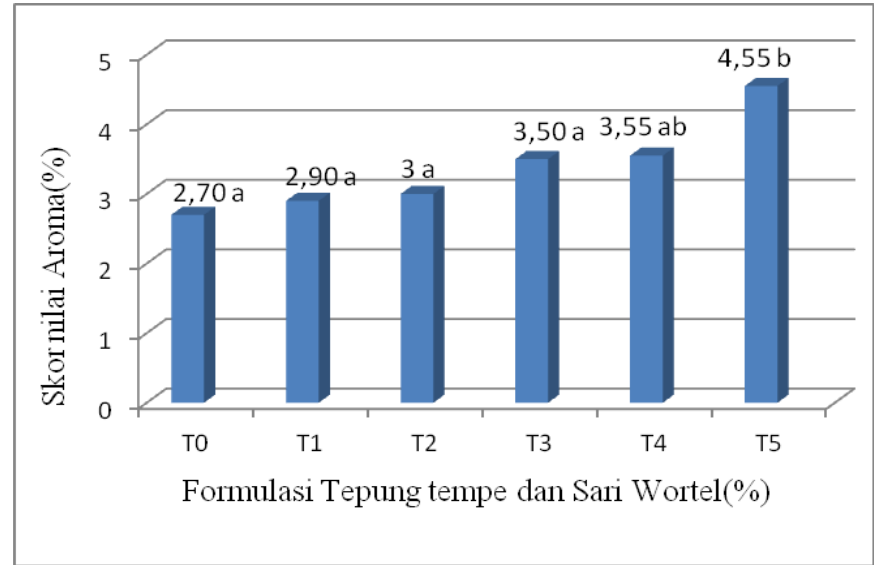

Gambar 9. Grafik pengaruh hubungan formulasi tepung tempe dan sari wortel terhadap skor nilai aroma Mie basah kaya gizi

Formulasi tepung tempe dan sari wortel pada pembuatan mie basah memberikan pengaruh nyata terhadap skor nilai aroma pada mie basah yang dihasilkan. Skor nilai tertinggi aroma mie basah diperoleh pada perlakuan T5 $(4,55)$ dengan kriteria suka mendekati sangat suka dan terendah diperoleh pada perlakuan T0 $(2,7)$ dengan kriteria agak suka. Semakin tinggi jumlah tepung tempe dan semakin rendah sari wortel yang digunakan, maka tingkat kesukaan panelis terhadap aroma tepung tempe semakin tinggi. Hal ini sesuai dengan penelitian Zuraidah (2006), yang menyatakan bahwa semakin tinggi jumlah tempe, maka tingkat kesukaan panelis terhadap aroma mie basah yang dihasilkan semakin meningkat.

\section{Skor Nilai Rasa}

Grafik pengaruh hubungan formulasi tepung tempe dan sari wortel terhadap skor nilai Rasa mi basah dapat dilihat pada Gambar 10.

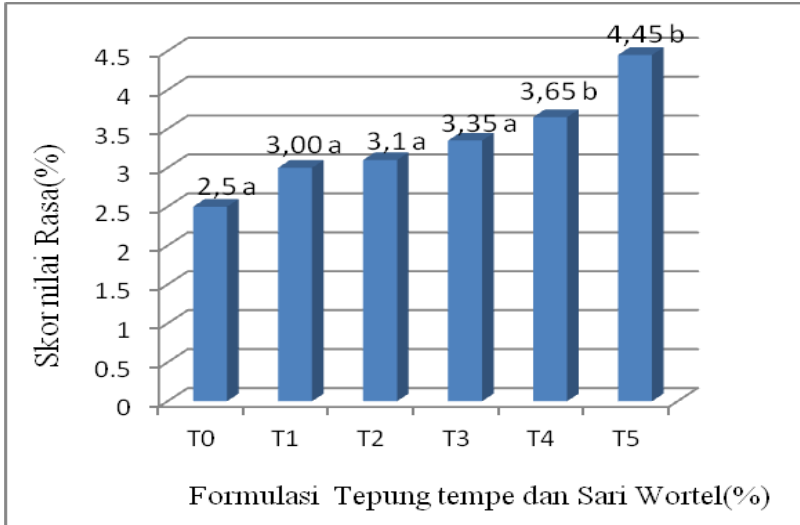

Gambar 10. Grafik hubungan formulasi tepung tempe dan sari wortel terhadap Skor Nilai Rasa mie basah kaya gizi

Hasil analisa menunjukkan formulasi tepung tempe dan sari wortel pada mie basah memberikan pengaruh nyata terhadap skor nilai rasa pada mie basah yang dihasilkan. Pada Gambar 10, skor nilai rasa tertinggi diperoleh pada perlakuan T5 (formulasi tepung tempe 30\%) yaitu sebesar 4,45 dengan kriteria suka dan nilai terendah pada perlakuan T0 (sebagai kontrol 100\%) yaitu sebesar 2,5 dengan kriteria mendekati agak suka. Hal ini disebabkan semakin tinggi formulasi tepung tempe maka tingkat kesukaan panelis terhadap rasa semakin meningkat. Rasa pada mi juga dipengaruhi oleh komponen penyusun lainnya seperti garam,dan telur. Hal ini sesuai dengan pendapat [14] yang menjelaskan bahwa rasa dipengaruhi beberapa faktor, seperti senyawa kimia, suhu, konsentrasi bahan-bahan penyusun mie dan interaksi komponen-komponen rasa yang lain

\section{SIMPULAN DAN SARAN \\ SIMPULAN}

Berdasarkan hasil penelitian dan pembahasan dapat disimpulkan sebagai berikut :

a. Formulasi tepung tempe dan sari wortel pada pembuatan mie basah kaya gizi berpengaruh secara nyata terhadap kadar protein, semua organoleptik (Tekstur, warna, aroma, dan rasa), tetapi tidak berpengaruh nyata dengan kadar air dan kadar betakaroten.

b. Semakin tinggi persentasi penambahan tepung tempe dan semakin rendah kadar sari wortelnya maka kadar protein semakin meningkat, tetapi kadar air dan kadar betakaroten semakin menurun.

c. Semakin tinggi persentase formulasi tepung tempe dan sari wortel maka skor nilai tekstur, aroma, warna, dan rasa semakin meningkat dan disukai panelis.

d. Perlakuan terbaik diperoleh pada perlakuan T5 (Formulasi tepung tempe 30\%+10\%) yaitu dengan nilai kadar air 19,73\%, kadar protein 11,22\%, dan mempunyai tekstur yang kenyal, berwarna Kuning agak oranye, aroma sangat disukai dan rasa disukai panelis.

\section{SARAN}

Berdasarkan hasil penelitian yang dilakukan maka dapat dikemukakan saran-saran sebagai berikut:

a. Untuk mendapatkan mie basah yang bergizi dan disukai panelis disarankan menggunakan perlakuan T5 dengan formulasi 75 gram tepung tempe $+25 \mathrm{ml}$ sari wortel +150 gram tepung terigu. 
b. Untuk penelitian lebih lanjut sebaiknya dilakukan variasi formulasi dengan tepung lainnya sehingga diperoleh informasi lebih lengkap hasil penelitian mengenai mie basah.

\section{DAFTAR RUJ UKAN}

[1] Muhajir. 2007. Peningkatan gizi Mie instan dari campuran tepung terigu dan tepung ubi jalar melalui penambahan tepung tempe dan tepung ikan. Sumatera utara. Medan.

[2] J oe, 2011. Kandungan gizi tempe Pustaka Sinar Harapan, Jakarta.

[3] Sarwono, B, Membuat Tempe dan Oncom. Jakarta : Penebar Swadaya, 2003.

[4] Soenardi.2002. Komposisi nilai gizi mi basah. Kanisius Yogyakarta.

[5] Kumalaningsih, S. 2006. Antioksidan alami penangkal Radikal Bebas. Trubus Agisarana. Surabaya.

[6] Hastuti, P.S., E. Sutriswati dan I.S. Utami. 1985. Tepung sorgum ( sorgum vulgare ) sebagai pengganti tepung gandum dalam pembuatan Mie dan Roti Tawar. Jurnal. Fakultas Teknologi Pertanian UGM. Yogyakarta.

[7] Royaningsih, S. Dan P. Pangloli. 1988. Pembuatan Mie Basah (boiled noodle ) dari campuran Terigu dan Tepung Sagu. Di dalam E. S. Heruwati ( Ed). Prosiding Seminar Penelitian Pasca Panen Pertanian. Balitbang Penelitian, Dapartemen Pertanian Bogor.

[8] Marzempi, D. Sastrodipuro, Alman dan Asward. 1994. Penggunaan Tepung ubi kayu sebagai bahan substitusi terigu dalam pembuatan mi kering.

[9] Nasution. 2005 substitusi bubur wortel dengan Tepung Terigu pada Pembuatan Mie Basah Program Sarjana Fakultas Kesehatan Masyarakat Universitas Sumatera Utara .

[10] Yitnosumatro, S., 1991.Percobaan perancangan, analisis dan interpretasi.PT.Gramedia Utama J akarta.

[11] Cahyono, B. 2002.Wortel Teknik Budi Daya Analisis Usaha Tani. Yogyakarta: Kanisius.

[12] Astawan, M. 2008. Proses pembuatan Mie basah. Penebar Swadaya. J akarta.

[13] Lydia 2008 N. Fortifikasi Mi dengan tepung tempe. Prosiding seminar nasional sains dan pendidikan sains UKSW. Fakultas sains dan matematika. Universitas kristen satya wacana.

[14] Winarno, F.,G. 2004. Kimia pangan dan gizi Gramedia Pustaka Utama, jakarta. 